3-1-2014

\title{
Removal of Hazardous Heavy Metals From Aqueous Environment by Low-Cost Adsorption Materials
}

\author{
Pei Sin Keng \\ International Medical University \\ Siew Ling Lee \\ Universiti Teknologi Malaysia \\ Sie Tiong $\mathrm{Ha}$ \\ Universiti Tunku Abdul Rahman \\ Yung Tse Hung \\ Cleveland State University, y.hung@csuohio.edu \\ Siew Teng Ong \\ Universiti Tunku Abdul Rahman
}

Follow this and additional works at: https://engagedscholarship.csuohio.edu/encee_facpub

How does access to this work benefit you? Let us know!

Publisher's Statement

The final publication is available at Springer via http://dx.doi.org/10.1007/s10311-013-0427-1

\section{Recommended Citation}

Keng, Pei Sin; Lee, Siew Ling; Ha, Sie Tiong; Hung, Yung Tse; and Ong, Siew Teng, "Removal of Hazardous Heavy Metals From Aqueous Environment by Low-Cost Adsorption Materials" (2014). Civil and Environmental Engineering Faculty Publications. 100.

https://engagedscholarship.csuohio.edu/encee_facpub/100

This Article is brought to you for free and open access by the Civil and Environmental Engineering at EngagedScholarship@CSU. It has been accepted for inclusion in Civil and Environmental Engineering Faculty Publications by an authorized administrator of EngagedScholarship@CSU. For more information, please contact library.es@csuohio.edu. 


\title{
Removal of hazardous heavy metals from aqueous environment by low-cost adsorption materials
}

\author{
Pei-Sin Keng Siew-Ling Lee Sie-Tiong Ha \\ Yung-Tse Hung Siew-Teng Ong
}

\begin{abstract}
The rapid growth of the human population and industrialization in the world has indirectly increased environmental problems such as water, air and land pollution. Amongst all, heavy metals can be considered as the most problematic pollutants. Numerous efforts have been attempted to minimize the impact of heavy metals. This chapter discusses the recent developments and technical applicability of different treatment methods for heavy metal removal. The adsorption process using various lowcost materials as the potential alternative for heavy metal removal is being highlighted and summarized.
\end{abstract}

Keywords Heavy metals - Chemical precipitation · Ion exchange · Membrane filtration · Adsorption ·

Low-cost adsorbents

\section{Introduction}

Heavy metals may be defined as the elements having atomic weights between 63.5 and 200.6 and have a minimum specific gravity of 5 (Srivastava and Majumder 2008). These metallic agents, once concentrated in the biosphere, generally persist and are not broken down. Therefore, water pollution by heavy metals poses one of the most serious environmental problems and of the most difficult to solve. Although some of the heavy metals such as iron, zinc, copper, iodine and molybdenum are recognized as essential for human health, some heavy metals are regarded as purely toxic metals. These include arsenic, nickel and lead, which are of widespread use and frequently found in industrial wastewater.

Arsenic (As) is a metalloid belonging to group 15 of the periodic table with atomic number of 33 and atomic weight of 74.92. The widespread usage of As can be found in wood preservation, making of special glass and semi-conductors and insecticides. However, due to its toxicity, the ingestion and inhalation of As and its compounds can cause various health problems. For instance, infertilities and miscarriages in women and dermatological effect which causes skin cancer are often associated with the prolonged and high exposure to As or its compounds (Hindmarsh and McCurdy 1986).

Nickel (Ni) is a silvery white, hard, malleable and ferromagnetic metallic element belonging to group 10 of the periodic table with atomic number of 28 and atomic weight of 58.69. $\mathrm{Ni}$ is corrosion resistant and used primarily for making of stainless steel and many other corrosion resistant alloys. The possible routes of Ni entry to human beings are through inhalation, ingestion and skin contact. Nevertheless, absorbed $\mathrm{Ni}$ is unable to be metabolized by human body. According to the Agency for Toxic Substances and 
Disease Registry (ATSDR) of United States, the reference values for $\mathrm{Ni}$ in healthy adults are $0.2 \mu \mathrm{g} / \mathrm{L}$ in serum and $13 \mu \mathrm{g} / \mathrm{L}$ in urine (ATSDR 2005). For dermal contact of $\mathrm{Ni}$, it causes dermatitis which is the most adverse health effect associated with Ni exposure.

Lead $(\mathrm{Pb})$ is a soft, malleable, ductile and dense metal. Due to its corrosion resistant characteristics, $\mathrm{Pb}$ has been historically used in plumbing. The other major use of $\mathrm{Pb}$ is in lead-acid batteries manufacturing and formation of lead alloys. However, like As, lead is toxic in nature. The high exposure to $\mathrm{Pb}$ can increase the risk of kidney failure, disruption of central nervous system, brain damage and even death. This article is an abridged version of chapter 8 published in the book Environmental Chemistry for a Sustainable World (ECSW), volume 3, by Keng et al. (2013, ECSW book chapter).

\section{Heavy metal removal: conventional and emerging methods}

Extensive research and financial resources have been spent on the treatment of heavy metal pollution especially in industrial wastewater which is contaminated by heavy metals. These technologies include conventional physicochemical methods and biological treatments, where the latter have gradually getting momentum because they are more eco-friendly and cost effective compare to the conventional techniques.

\section{Chemical precipitation}

Amongst all the physical chemical methods, chemical precipitation is the most common and effective method used in the industry for treatment of wastewater containing heavy metals because it is relatively easy and inexpensive to operate (Kung and Jung 2001). This technique is employed in almost $75 \%$ of electroplating facilities to treat wastewater (Karthikeyan et al. 1996). Generally, the metals are precipitated as insoluble hydroxides, carbonates or sulphides and separated from water by sedimentation and filtration (Table 1).

Although this technique is reported as the most widely used method for heavy metal removal in industry effluent, still it suffers from some limitations. For instance, hydroxide precipitation requires a large amount of chemicals to reduce metals to an acceptable level prior discharge especially if the effluents have high acidity where large amounts of lime are required for neutralization. In this case, excessive secondary sludge, such as gypsum $\left(\mathrm{CaSO}_{4} \cdot 2 \mathrm{H}_{2} \mathrm{O}\right)$, is produced that requires further treatment. These secondary precipitates not only increase the costs of sludge handling but also give long-term environmental impacts (Kurniawan et al. 2006). Secondly, some metal hydroxides are amphoteric, and the mixed metals create a problem using hydroxide precipitation since the ideal $\mathrm{pH}$ for one metal may change another metal back into solution. On top of these, some complexing agents present in the wastewater will inhibit the efficacy of metal hydroxide precipitation (Fu and Wang 2011).

Ion exchange

Ion exchange is the process through which an ion is removed out of an aqueous solution and is replaced by another ionic species. It has been continuously used in the treatment of heavy metals due to several advantages, such as high treatment capacity, high selectivity for certain heavy metal ions and most significantly, fast kinetics and most importantly it reduces the major problem faces in chemical precipitation handling and disposal of large amount of sediments and sludge (Lacour et al. 2001; AboFarha et al. 2009; Al-Enezi et al. 2004). Strongly acidic resins with sulphonic acid groups $\left(-\mathrm{SO}_{3} \mathrm{H}\right)$ and weakly acid resins with carboxylic acid groups $(-\mathrm{COOH})$ are the most common cation exchangers. The degree of exchange that occurs depends on the size and ionic charge of the metal cations, initial metal concentration, nature (both physical and chemical) of the ion exchange substance, $\mathrm{pH}$ and temperature (Lee et al. 2006a; Al-Enezi et al. 2004). Since resins have different swelling characteristics, the total exchange capacity on a volumetric basis ranged from 1.0 to $4.0 \mathrm{meq} / \mathrm{mL}$. Though the efficiency of ion exchange resins for heavy metal removal is evident, the cost incurred prohibits the treatment of highly concentrated wastewater. Thereby, it is typically used as a polishing step after precipitation.

Membrane filtration

The ultimate objective of most of the traditional methods in heavy metal treatments is not the recovery of the metal but rather its elimination. However, recovery of heavy metals shows greater benefits. It allows reuse of the metals and thus provides further economic and environmental benefits by reducing the disposal costs and raw material requirements. In this case, membrane processes exert as an alternative for heavy metal recovery. Other advantages of this technique including fewer chemicals are used in the process, simple operation, less space consuming and can be easily combined with other separation processes for better removal efficiency. The membrane processes used for wastewater treatment containing heavy metals including microfiltration (MF), ultrafiltration (UF), nanofiltration (NF), reverse osmosis (RO) and electrodialysis (ED) depending on the size of the particle that can be 
Table 1 Removal of heavy metals using chemical precipitation

\begin{tabular}{|c|c|c|c|c|c|c|}
\hline Cation (heavy metal) & $\begin{array}{l}\text { Anion } \\
\text { (precipitant) }\end{array}$ & $\begin{array}{l}\text { Optimum } \\
\mathrm{pH}\end{array}$ & $\begin{array}{l}\text { Contact } \\
\text { time }(\mathrm{h})\end{array}$ & $\begin{array}{l}\text { Initial metal } \\
\text { concentration }\end{array}$ & $\begin{array}{l}\text { Removal } \\
\text { efficiency (\%) }\end{array}$ & Reference \\
\hline $\mathrm{Cu}^{2+}, \mathrm{Cr}^{4+}$ & $\begin{array}{l}\mathrm{Ca}(\mathrm{OH})_{2}, \mathrm{NaOH} \\
\mathrm{Na}_{2} \mathrm{CO}_{3}\end{array}$ & $12.0,8.7$ & 2 & $\begin{array}{c}48.51 \mathrm{mg} / \mathrm{L} \\
30 \mathrm{mg} / \mathrm{L}\end{array}$ & $98.6,99.97$ & $\begin{array}{l}\text { Mirbagheri and } \\
\text { Hosseini (2005) }\end{array}$ \\
\hline $\begin{array}{c}\mathrm{Cd}^{2+}, \mathrm{Cr}^{3+}, \mathrm{Cu}^{2+}, \\
\mathrm{Ni}^{2+}, \mathrm{Pb}^{2+}, \mathrm{Zn}^{2+}\end{array}$ & $\mathrm{Ca}(\mathrm{OH})_{2}, \mathrm{NaOH}$ & 8.18 .3 & 24 & $0.129 .7 \mathrm{mg} / \mathrm{L}$ & 50100 & $\begin{array}{l}\text { Meunier et al. } \\
\text { (2006) }\end{array}$ \\
\hline $\begin{array}{l}\text { Soil, fly ash and sewage } \\
\text { leachates } \mathrm{Al}^{3+}, \mathrm{Ba}^{2+} \\
\mathrm{Ca}^{2+}, \mathrm{Cd}^{2+}, \mathrm{Co}^{2+}, \mathrm{Cr}^{3+}, \\
\mathrm{Cu}^{2+}, \mathrm{Fe}, \mathrm{Mg}^{2+}, \mathrm{Mn}, \\
\left.\mathrm{Ni}^{2+}, \mathrm{Pb}^{2+}, \mathrm{Zn}^{2+}, \mathrm{P}, \mathrm{S}\right)\end{array}$ & $\begin{array}{l}\mathrm{NaOH}, \mathrm{Ca}(\mathrm{OH})_{2}, \\
\mathrm{NaOH} / \mathrm{Na}_{2} \mathrm{~S}, \\
\mathrm{NaOH} / \mathrm{Na}_{2} \mathrm{CO}_{3}, \\
\mathrm{NaOH} / \mathrm{Na}_{2} \mathrm{HPO}_{4}\end{array}$ & $\begin{array}{l}5.0 \\
7.5 \\
7.5 \\
8.0\end{array}$ & 0.3 & $\begin{array}{l}0.13719 \mathrm{mg} / \mathrm{L}^{\mathrm{a}} \\
1.3811,100 \mathrm{mg} / \mathrm{L}^{\mathrm{b}} \\
0.23827 \mathrm{mg} / \mathrm{L}^{\mathrm{c}}\end{array}$ & $\begin{array}{l}0.0100^{\mathrm{a}} \\
23.9100^{\mathrm{b}} \\
3.5100^{\mathrm{c}}\end{array}$ & $\begin{array}{l}\text { Djedidi et al. } \\
\text { (2009) }\end{array}$ \\
\hline $\mathrm{Ni}^{2+}, \mathrm{Co}^{2+}, \mathrm{Cu}^{2+}$ & $\mathrm{Na}_{2} \mathrm{~S}$ & 5.8111 .6 & 0.52 & $502051 \mathrm{mg} / \mathrm{L}$ & 66.999 .9 & $\begin{array}{l}\text { Lewis and van } \\
\text { Hille } \\
(2006)\end{array}$ \\
\hline $\mathrm{Zn}^{2+}$ & $\mathrm{Na}_{2} \mathrm{~S}$ & 6.5 & NA & $7,500 \mathrm{mg} / \mathrm{L}$ & $\begin{array}{l}99.9 \\
(<0.01 \mathrm{mg} / \mathrm{L})\end{array}$ & $\begin{array}{l}\text { Veeken et al. } \\
\text { (2003) }\end{array}$ \\
\hline $\begin{array}{l}\text { Acid mine drainage } \\
\left(\mathrm{Fe}^{2+}, \mathrm{Mn}^{2+}\right)\end{array}$ & $\begin{array}{l}1,3 \text { benzenediamido } \\
\text { ethane thiolate }\end{array}$ & 4.5 & 20 & $\begin{array}{l}194 \mathrm{mg} / \mathrm{L} \\
4.65 \mathrm{mg} / \mathrm{L}\end{array}$ & $\begin{array}{l}99.9(<0.009 \mathrm{ppm}) \\
97.3\end{array}$ & $\begin{array}{l}\text { Matlock et al. } \\
\text { (2002) }\end{array}$ \\
\hline
\end{tabular}

NA Not available

${ }^{a}$ Refers to the soil leachates

b Refers to the fly ash leachates

${ }^{c}$ Refers to the sewage sludge leachates

retained (Table 2). The membrane techniques that are often used for heavy metal removal are UF, NF, RO and ED. However, the performance of $\mathrm{RO}$ and its lifetime are highly sensitive to wastewater properties. The accumulation of particulate and colloidal matters at the feed side of the membrane surface caused membrane fouling and permeate flux decline (Lee et al. 2006b).

\section{Adsorption}

Adsorption is known as an efficient, convenient and economic method for wastewater treatment. The flexibility in design and operation, high removal efficiency and the possibility for most of the adsorbents to be regenerated and reuse by suitable desorption process have made adsorption process gaining its popularity (Krishnani et al. 2008; Elouear et al. 2008; Afkhami et al. 2010; Salehi et al. 2012). Activated carbon (AC) is being recognized as one of the most popular adsorbents used in the removal of heavy metal contaminants. AC has been used efficiently in both

Table 2 Pore size of the membrane processes

\begin{tabular}{ll}
\hline Membrane process & Pore size $(\mathrm{nm})$ \\
\hline Microfiltration & $0.110 \mu \mathrm{m}(>100)$ \\
Ultrafiltration & $0.0050 .2 \mu \mathrm{m}(5200)$ \\
Nanofiltration & $0.0010 .01 \mu \mathrm{m}(<10)$ \\
\hline
\end{tabular}

batch and column studies due to its large micropore and mesopore volumes. However, the drawback of AC is it remains as an expensive material because of depleting source of commercial coal-based AC. Higher cost is accounted for higher quality of activated carbon. Another limitation of $\mathrm{AC}$ adsorption in heavy metal removal is its high affinity towards organic molecules. As a result, these kinds of high molecular weight organic compounds will block the heavy metal ions from reaching the adsorbents bed. Due to these problems, many researchers have shown interest to search and explore on other potential adsorbents to replace AC.

\section{Utilization of low-cost adsorbents in heavy metals removal}

Techniques currently used for the removal of heavy metals from wastewaters are chemical precipitation, ion exchange, membrane filtration, electrolytic reduction, coagulation, solvent extraction and catalysis. However, owing to the drawbacks found in these techniques, there is thus a need to search for alternative process that could remove heavy metal that are commonly found in the industry effluent. In this regard, adsorption appeared to be an attractive alternative due to ease of operation. Besides, it can also be considered as an economical approach if it involves the 
Table 3 Adsorption capacities of metals by fly ash
These reported adsorption capacities are values obtained under specific conditions.

Readers are encouraged to refer to the original articles for information on experimental conditions

${ }^{\text {a }}$ In the unit of $\left(\mathrm{mg} \mathrm{g}^{-1}\right)$ unless specified

\begin{tabular}{|c|c|c|c|c|}
\hline Metals & Adsorbent & $\begin{array}{l}\text { Adsorption } \\
\text { capacity }^{\mathrm{a}}\end{array}$ & $\begin{array}{l}\text { Temperature } \\
\left({ }^{\circ} \mathrm{C}\right)\end{array}$ & References \\
\hline \multirow[t]{2}{*}{ As(III) } & Fly ash coal char & 3.789 .2 & 25 & Pattanayak et al. (2000) \\
\hline & Fly ash brown coal char & 25.132 .1 & 25 & Polowczyk et al. (2011) \\
\hline \multirow[t]{2}{*}{$\operatorname{As}(\mathrm{V})$} & Fly ash & 7.727 .8 & 20 & Diamadopoulos et al. (1993) \\
\hline & Fly ash coal char & 0.0234 .5 & 25 & Pattanayak et al. (2000) \\
\hline \multirow[t]{4}{*}{$\mathrm{Cd}(\mathrm{II})$} & Fly ash & 0.670 .83 & 20 & Bayat (2002a) \\
\hline & Bagasse fly ash & 1.242 .0 & 3050 & Gupta et al. (2003) \\
\hline & Coal Fly ash & 18.98 & 25 & Papandreou et al. (2007) \\
\hline & $\mathrm{NaOH}$ activated fly ash & 30.21 & 2025 & Visa et al. (2012) \\
\hline \multirow[t]{2}{*}{$\mathrm{Cr}(\mathrm{III})$} & Fly ash & 52.6106 .4 & 2040 & Cetin and Pehlivan (2007) \\
\hline & Fly ash porous pellet & 22.88 & 25 & Papandreou et al. (2011) \\
\hline \multirow[t]{4}{*}{$\mathrm{Cr}(\mathrm{VI})$} & Fly ash chitosan composite & 33.27 & 15 & Wen et al. (2011) \\
\hline & Fly ash & 1.38 & 3060 & Banerjee et al. (2004) \\
\hline & Fe impregnated fly ash & 1.82 & 3060 & Banerjee et al. (2004) \\
\hline & Al impregnated fly ash & 1.67 & 3060 & Banerjee et al. (2004) \\
\hline $\mathrm{Cs}(\mathrm{I})$ & Fly ash zeolite & 443.9 & 25 & Mimura et al. (2001) \\
\hline \multirow[t]{6}{*}{$\mathrm{Cu}(\mathrm{II})$} & Fly ash & 0.630 .81 & 25 & Lin and Chang (2001) \\
\hline & Fly ash & 0.76 & 32 & Rao et al. (2003) \\
\hline & Coal Fly ash pellets & 20.92 & 25 & Papandreou et al. (2007) \\
\hline & Coal fly ash (CFA) & 178.5249 .1 & 3060 & Hsu et al. (2008) \\
\hline & CFA 600 & 126.4214 .1 & 3060 & Hsu et al. (2008) \\
\hline & CFA NAOH & 76.7137 .1 & 3060 & Hsu et al. (2008) \\
\hline \multirow[t]{3}{*}{$\mathrm{Hg}(\mathrm{II})$} & Fly ash & 11.0 & 3060 & Banerjee et al. (2004) \\
\hline & Fe impregnated fly ash & 12.5 & 3060 & Banerjee et al. (2004) \\
\hline & $\mathrm{Al}$ impregnated fly ash & 13.4 & 3060 & Banerjee et al. (2004) \\
\hline \multirow[t]{4}{*}{$\mathrm{Ni}(\mathrm{II})$} & Fly ash & 9.014 .0 & 3060 & Banerjee et al. (2003) \\
\hline & Fe impregnated fly ash & $9.8 \quad 14.93$ & 3060 & Banerjee et al. (2003) \\
\hline & Al impregnated fly ash & 1015.75 & 3060 & Banerjee et al. (2003) \\
\hline & Bagasse fly ash & 1.121 .70 & 3050 & Gupta et al. (2003) \\
\hline \multirow[t]{4}{*}{$\mathrm{Pb}(\mathrm{II})$} & Fly ash zeolite & 70.6 & 20 & Gan (2000) \\
\hline & Bagasse fly ash & 285566 & 3050 & Goswami and Das (2000) \\
\hline & Fly ash porous pellet & 45.54 & 25 & Papandreou et al. (2011) \\
\hline & $\mathrm{NaOH}$ activated fly ash & 2000.0 & 2025 & Visa et al. (2012) \\
\hline \multirow[t]{11}{*}{$\mathrm{Zn}(\mathrm{II})$} & Fly ash & 6.513 .3 & 3060 & Banerjee et al. (2003) \\
\hline & Fe impregnated fly ash & 7.515 .5 & 3060 & Banerjee et al. (2003) \\
\hline & $\mathrm{Al}$ impregnated fly ash & 7.015 .4 & 3060 & Banerjee et al. (2003) \\
\hline & $\mathrm{NaOH}$ activated fly ash & 18.87 & 2025 & Visa et al. (2012) \\
\hline & Fly ash & 0.252 .8 & 20 & Bayat (2002a) \\
\hline & Afsin Elbistan fly ash & 0.251 .19 & 20 & Bayat 2002b \\
\hline & Seyitomer fly ash & $0.07 \quad 1.30$ & 20 & Bayat 2002b \\
\hline & Bagasse fly ash & 2.342 .54 & 3050 & Gupta and Ali (2000) \\
\hline & Bagasse fly ash & 13.21 & 30 & Gupta et al. (2003) \\
\hline & Fly ash & 0.0680 .75 & 055 & Weng and Huang (2004) \\
\hline & Fly ash porous pellet & 17.66 & 25 & Papandreou et al. (2011) \\
\hline
\end{tabular}

utilization of low-cost materials as the adsorbent. Generally, the low-cost adsorbent materials are referred to those available at free cost and exist abundantly in nature. They may also represent the unused resources after a manufacturing process with serious disposal problems. Apparently, utilization of naturally occurring material or locally available agricultural waste materials or industrial by-products as the adsorbents in removing heavy metals 
Table 4 Adsorption capacities of metals by rice husk

\begin{tabular}{|c|c|c|c|c|}
\hline Metals & Adsorbent & $\begin{array}{l}\text { Adsorption } \\
\text { capacity }^{\mathrm{a}}\end{array}$ & $\begin{array}{l}\text { Temperature } \\
\left({ }^{\circ} \mathrm{C}\right)\end{array}$ & References \\
\hline $\mathrm{As}(\mathrm{III})$ & $\begin{array}{l}\text { Copolymer of iron and aluminium } \\
\text { impregnated with active silica } \\
\text { derived from rice husk ash }\end{array}$ & 146 & & Abo El Enein et al. (2009) \\
\hline \multirow[t]{2}{*}{$\mathrm{As}(\mathrm{V})$} & Rice husk & 615.11 & & Roy et al. (1993) \\
\hline & Quaternized rice husk & 18.98 & & Lee et al. (1999) \\
\hline \multirow[t]{3}{*}{$\mathrm{Au}(\mathrm{I})$} & Rice husk & 64.10 & 40 & Nakbanpote et al. (2002) \\
\hline & Rice husk & 50.50 & 30 & Nakbanpote et al. (2002) \\
\hline & Rice husk & 39.84 & 20 & Nakbanpote et al. (2002) \\
\hline $\mathrm{Cd}(\mathrm{II})$ & $\begin{array}{l}\text { Partial alkali digested and } \\
\text { autoclaved rice husk }\end{array}$ & 16.7 & & Krishnani et al. (2008) \\
\hline \multirow[t]{8}{*}{$\mathrm{Cd}(\mathrm{II})$} & Phosphate treated rice husk & 103.09 & 20 & Ajmal et al. (2003) \\
\hline & Rice husk & 73.96 & & Ye et al. (2010) \\
\hline & Rice husk & 4 & & Tarley et al. (2004) \\
\hline & $\mathrm{NaOH}$ activated rice husk & 125.94 & & Ye et al. (2010) \\
\hline & $\mathrm{NaOH}$ activated rice husk & 7 & & Tarley et al. (2004) \\
\hline & Rice husk ash & 3.04 & & \\
\hline & Polyacrylamide grafted rice husk & 0.889 & & Sharma et al. (2009) \\
\hline & $\begin{array}{l}\text { Partial alkali digested and } \\
\text { autoclaved rice husk }\end{array}$ & 9.57 & & Krishnani et al. (2008) \\
\hline $\mathrm{Cr}(\mathrm{III})$ & Rice husk & 1.90 & & Marshall et al. (1993) \\
\hline \multirow[t]{3}{*}{$\mathrm{Cr}(\mathrm{VI})$} & Rice husk ash & 26.31 & & \\
\hline & Formaldehyde treated rice husk & 10.4 & & Bansal et al. (2009) \\
\hline & Pre boiled rice husk & 8.5 & & Bansal et al. (2009) \\
\hline \multirow[t]{14}{*}{$\mathrm{Cu}(\mathrm{II})$} & Rice husk & 0.2 & & Srivastava et al. (2008) \\
\hline & Rice husk & 7.1 & & Nakbanpote et al. (2007) \\
\hline & Rice husk ash & 11.5191 & & Feroze et al. (2011) \\
\hline & Raw rice hush & 4.90 & & Luo et al. (2011) \\
\hline & Expending rice husk & 8.02 & & Luo et al. (2011) \\
\hline & RH cellulose & 7.7 & & Nakbanpote et al. (2007) \\
\hline & $\begin{array}{l}\text { Rice husk heated to } 300{ }^{\circ} \mathrm{C} \\
\text { (RHA300) }\end{array}$ & 6.5 & & Nakbanpote et al. (2007) \\
\hline & $\begin{array}{l}\text { Rice husk heated to } 500{ }^{\circ} \mathrm{C} \\
\text { (RHA500) }\end{array}$ & 16.1 & & Nakbanpote et al. (2007) \\
\hline & $\begin{array}{l}\text { Microwave incinerated rice husk } \\
\text { ash }\left(800{ }^{\circ} \mathrm{C}\right)\end{array}$ & 3.497 & & Johan et al. (2011) \\
\hline & $\begin{array}{l}\text { Microwave incinerated rice husk } \\
\text { ash }\left(500{ }^{\circ} \mathrm{C}\right)\end{array}$ & 3.279 & & Johan et al. (2011) \\
\hline & $\begin{array}{l}\text { Partial alkali digested and } \\
\text { autoclaved rice husk }\end{array}$ & 10.9 & & Krishnani et al. (2008) \\
\hline & Carbonized rice husk & 42.1 & 15 & Ye et al. (2012) \\
\hline & Carbonized rice husk & 45.5 & 25 & Ye et al. (2012) \\
\hline & Carbonized rice husk & 55.2 & 35 & Ye et al. (2012) \\
\hline $\mathrm{Fe}(\mathrm{II})$ & $\begin{array}{l}\text { Copolymer of iron and aluminium } \\
\text { impregnated with active silica } \\
\text { derived from rice husk ash }\end{array}$ & 222 & & Abo El Enein et al. (2009) \\
\hline \multirow[t]{4}{*}{$\mathrm{Hg}(\mathrm{II})$} & Rice husk ash & 6.72 & 30 & Feng et al. (2004) \\
\hline & Rice husk ash & 9.32 & 15 & Feng et al. (2004) \\
\hline & $\begin{array}{l}\text { Polyaniline/rice husk ash } \\
\text { nanocomposite }\end{array}$ & Not determined & & Ghorbani et al. (2011) \\
\hline & $\begin{array}{l}\text { Partial alkali digested and } \\
\text { autoclaved rice husk }\end{array}$ & 36.1 & & Krishnani et al. (2008) \\
\hline
\end{tabular}


Table 4 continued

These reported adsorption capacities are values obtained under specific conditions. Readers are encouraged to refer to the original articles for information on experimental conditions

${ }^{\text {a }}$ In the unit of $\left(\mathrm{mg} \mathrm{g}^{-1}\right)$ unless specified

\begin{tabular}{|c|c|c|c|c|}
\hline Metals & Adsorbent & $\begin{array}{l}\text { Adsorption } \\
\text { capacity }^{\mathrm{a}}\end{array}$ & $\begin{array}{l}\text { Temperature } \\
\left({ }^{\circ} \mathrm{C}\right)\end{array}$ & References \\
\hline \multirow[t]{2}{*}{$\mathrm{Mn}$} & $\begin{array}{l}\text { Copolymer of iron and aluminium } \\
\text { impregnated with active silica } \\
\text { derived from rice husk ash }\end{array}$ & 158 & & Abo El Enein et al. (2009) \\
\hline & $\begin{array}{l}\text { Partial alkali digested and } \\
\text { autoclaved rice husk }\end{array}$ & 8.30 & & Krishnani et al. (2008) \\
\hline \multirow[t]{2}{*}{$\mathrm{Ni}(\mathrm{II})$} & $\begin{array}{l}\text { Microwave irradiated rice husk } \\
\text { (MIRH) }\end{array}$ & 1.17 & 30 & Pillai et al. (2009) \\
\hline & $\begin{array}{l}\text { Partial alkali digested and } \\
\text { autoclaved rice husk }\end{array}$ & 5.52 & & Krishnani et al. (2008) \\
\hline \multirow[t]{4}{*}{$\mathrm{Pb}(\mathrm{II})$} & Rice husk ash & 12.61 & 30 & Feng et al. (2004) \\
\hline & Rice husk ash & 12.35 & 15 & Feng et al. (2004) \\
\hline & $\begin{array}{l}\text { Partial alkali digested and } \\
\text { autoclaved rice husk }\end{array}$ & 58.1 & & Krishnani et al. (2008) \\
\hline & Tartaric acid modified rice husk & 21.55 & & Tarley et al. (2004) \\
\hline \multirow[t]{5}{*}{$\mathrm{Zn}(\mathrm{II})$} & Rice husk ash & 14.30 & & \\
\hline & Rice husk ash & 7.7221 & & Feroze et al. (2011) \\
\hline & Rice husk ash & 5.88 & & \\
\hline & $\begin{array}{l}\text { Partial alkali digested and } \\
\text { autoclaved rice husk }\end{array}$ & 8.14 & & Krishnani et al. (2008) \\
\hline & $\begin{array}{l}\text { Rice husk polyaniline } \\
\text { nanocomposite }\end{array}$ & 24.3 & & Ghorbani et al. (2012) \\
\hline
\end{tabular}

from wastewaters is not only cost effective in heavy metal removal, but it also contributes to a zero waste situation in the environment.

A numerous studies have been carried out to investigate as well as to further improve the usage of different low-cost adsorbent materials for adsorption of individual or multiple heavy metals in an aqueous solution. These low-cost adsorbents range from industrial by-products, agriculture waste to biosorbents, for example, wood bark, sawdust, mangoes teen peel, durian husk, oil palm empty fruit bunch, tea leaves, exhausted coffee, etc. In this section, some of the intensively studied low-cost adsorbents such as fly ash, rice husk, wheat straw, chitin and chitosan composites as well as algae and bacteria were discussed in terms of their efficiency for heavy metal removal. Recent reported adsorption capacities of the selected adsorbents are presented in Tables 3, 4, 5 and 6 to give some idea of adsorbent effectiveness. It is interesting to note that the reported values are strongly dependent on the experimental condition. Therefore, it is advisable for the reader to refer to the original work in order to have a better understanding on the specific conditions that have been imposed on the adsorption process.

Fly ash

Fly ash is an industrial by-product which is usually grey in colour, abrasive, mostly alkaline and refractory in nature. It contains mainly silica $\left(\mathrm{SiO}_{2}\right)$ of $\sim 47 \%$, alumina $\left(\mathrm{Al}_{2} \mathrm{O}_{3}\right)$ of $\sim 25 \%$, iron oxide $\left(\mathrm{Fe}_{2} \mathrm{O}_{3}\right)$ of $\sim 16 \%$ and calcium oxide $(\mathrm{CaO})$ of $\sim 5 \%$ with varying amounts of carbon, calcium, magnesium and sulphur. The variations that are commonly found in fly ash, either in terms of their chemical composition or physical properties, are most likely due to different sources of coal as well as diversity in the design of coal-fired boilers. However, an empirical formula for fly ash based on the dominance of certain key elements has been proposed as below (Iyer and Scott 2001):

$\mathrm{Si}_{1.0} \mathrm{Al}_{0.45} \mathrm{Ca}_{0.51} \mathrm{Na}_{0.047} \mathrm{Fe}_{0.039} \mathrm{Mg}_{0.020} \mathrm{~K}_{0.013} \mathrm{Ti}_{0.011}$.

Fly ash has been used effectively as raw material in cement and brick production, soil amendment and as filler in road works. Besides, it can also be converted into zeolite, another versatile material which is widely used as catalyst and adsorbent due to its outstanding high surface area and porosity. However, all the fly ash produced from the power industry cannot be reused by these applications. Consequently, most of the fly ash generated is disposed of as landfill, a practice which is under examination for environmental concerns. Therefore, continuing research efforts have been made to explore other applications prior to discarding in order to lessen the environmental burden. Since fly ash is enriched with $\mathrm{SiO}_{2}$ and contains a portion of unburned carbon, this material is potentially used as low-cost adsorbent to remove heavy metal from wastewaters. A lot of investigations have been reported 
Table 5 Adsorption capacities of metals by wheat based materials

\begin{tabular}{|c|c|c|c|}
\hline Metals & Adsorbent & $\begin{array}{l}\text { Adsorption } \\
\text { capacity }^{\mathrm{a}}\end{array}$ & References \\
\hline \multirow[t]{4}{*}{$\mathrm{Cd}(\mathrm{II})$} & Wheat straw & 39.22 & Farooq et al. (2011) \\
\hline & Wheat straw & 14.56 & Dang et al. (2009) \\
\hline & Wheat bran & 21.0 & $\begin{array}{c}\text { Farajzadeh and } \\
\text { Monji (2004) }\end{array}$ \\
\hline & Wheat bran & 101 & $\begin{array}{l}\text { Özer and Pirincci } \\
\text { (2006) }\end{array}$ \\
\hline \multirow[t]{2}{*}{$\mathrm{Cr}(\mathrm{III})$} & Wheat straw & 21.0 & Chojnacka (2006) \\
\hline & Wheat bran & 93.0 & $\begin{array}{l}\text { Farajzadeh and } \\
\text { Monji (2004) }\end{array}$ \\
\hline \multirow[t]{3}{*}{$\mathrm{Cr}(\mathrm{VI})$} & Wheat straw & 47.16 & $\begin{array}{l}\text { Dhir and Kumar } \\
\text { (2010) }\end{array}$ \\
\hline & Wheat bran & 35 & $\begin{array}{l}\text { Dupont and Guillon } \\
\text { (2003) }\end{array}$ \\
\hline & Wheat bran & 310.58 & Singh et al. (2009) \\
\hline \multirow[t]{5}{*}{$\mathrm{Cu}(\mathrm{II})$} & Wheat straw & 11.43 & Dang et al. (2009) \\
\hline & $\begin{array}{l}\text { Wheat straw citric } \\
\text { acid treated }\end{array}$ & 78.13 & Gong et al. (2008) \\
\hline & Wheat bran & 12.7 & Dupont et al. (2005) \\
\hline & Wheat bran & 6.85 & Wang et al. (2009) \\
\hline & Wheat bran & 15.0 & $\begin{array}{r}\text { Farajzadeh and } \\
\text { Monji (2004) }\end{array}$ \\
\hline $\mathrm{Hg}(\mathrm{II})$ & Wheat bran & 70.0 & $\begin{array}{r}\text { Farajzadeh and } \\
\text { Monji (2004) }\end{array}$ \\
\hline \multirow[t]{2}{*}{$\mathrm{Ni}(\mathrm{II})$} & Wheat straw & 41.84 & $\begin{array}{l}\text { Dhir and Kumar } \\
\text { (2010) }\end{array}$ \\
\hline & Wheat bran & 12.0 & $\begin{array}{l}\text { Farajzadeh and } \\
\text { Monji (2004) }\end{array}$ \\
\hline \multirow[t]{2}{*}{$\mathrm{Pb}(\mathrm{II})$} & Wheat bran & 62.0 & $\begin{array}{l}\text { Farajzadeh and } \\
\text { Monji (2004) }\end{array}$ \\
\hline & Wheat bran & 79.4 & $\begin{array}{l}\text { Özer and Pirincci } \\
\text { (2006) }\end{array}$ \\
\hline $\mathrm{Zn}(\mathrm{II})$ & Wheat bran & 16.4 & Dupont et al. (2005) \\
\hline $\mathrm{U}(\mathrm{VI})$ & Wheat straw & 19.234 .6 & Wang et al. (2011) \\
\hline
\end{tabular}

These reported adsorption capacities are values obtained under spe cific conditions. Readers are encouraged to refer to the original arti cles for information on experimental conditions

${ }^{\mathrm{a}}$ In the unit of $\left(\mathrm{mg} \mathrm{g}^{-1}\right)$

on the usage of fly ash in adsorption of heavy metal from aqueous solution and overall, the results obtained are encouraging.

Table 3 summarized the adsorption capacities of different heavy metals by different fly ashes. In some of the works, the researchers found that the unburned carbon in fly ash is partly activated during the combustion process, resulting in a relatively high surface area and good porosity (Wang and Li 2007; Lu et al. 2008). These characteristics of unburned carbon are similar to that of activated carbon; hence, fly ash could be a potential adsorbent and substitute of commercial activated carbon. Recently, biomass fly ash has attracted attention to be used as adsorbent in wastewaters treatment (Pengthamkeerati et al. 2008). It could be a better adsorbent as compared to other fly ash due to its higher percentage of unburned carbon.

Rice husk

In rice milling industries, rice husk which is the hard outer shell of the rice grain is generated as the major by-product or waste, accounting for almost $20 \%$ of the rice production. Throughout the world, the annual generation of rice husk was approximately 120 million tonnes in 2009, leading to serious environmental problems as the rice husk is usually disposed in the end of the production. It is considered as a lignocellulosic agricultural by-product that contains approximately $32 \%$ cellulose, $21 \%$ hemicelluloses, $21 \%$ lignin, $20 \%$ silica and $3 \%$ crude proteins (Nadzi et al. 2007).

Obviously, the utilization of this abundant scaly residue will yield economic as well as environmental dividends. Therefore, exploration of possible usage of the rice husk is of great significance in many rice producing countries. The high content of cellulose, a polymer contains three reactive hydroxyl groups has made rice husk a potential adsorbent material. However, both lignin and silica that present in rice husk tend to reduce the binding between accessible functional group on the surface of rice husk and adsorbate ions/molecules. Therefore, considerable researches have been carried out to modify or treat the rice husk via different methods prior to the application in heavy metal removal. Adsorption capacities of metals by untreated and treated rice husk are presented in Table 4.

Wheat straw and wheat bran

Wheat (Triticum aestivum) is the major food crop of the world. Every year, over 200 million tons of wheat straw are produced, and every 100 million ton of wheat can create 25 million tons of bran. In addition to their use as feed and fuel, large amounts of redundant wheat straw and bran must be disposed of. Therefore, finding new applications for these abundantly available waste materials is a challenge to the wheat production countries. The wheat straw is a lignocellulosic agricultural waste consisting of about $3440 \%$ cellulose, $2035 \%$ hemicellulose, $815 \%$ lignin and sugars as well as other compounds carrying different functional groups like carboxyl, hydroxyl, sulphydryl, amide and amine. As attempt to fully utilize these industry by-products, both wheat straw and wheat bran have been investigated for their adsorption behaviour towards metal ions (Table 5). The high adsorption capability of straw is closely related to high content of cellulose, presence of different functional groups and porosity of the material. 
Table 6 Adsorption capacities of metals by chitosan and chitosan composites
These reported adsorption capacities are values obtained under specific conditions. Readers are encouraged to refer to the original articles for information on experimental conditions

${ }^{\mathrm{a}}$ In the unit of $\left(\mathrm{mg} \mathrm{g}^{-1}\right)$

\begin{tabular}{|c|c|c|c|c|}
\hline Metal & Adsorbent & $\begin{array}{l}\text { Adsorption } \\
\text { capacity }^{\mathrm{a}}\end{array}$ & $\begin{array}{l}\text { Temperature } \\
\left({ }^{\circ} \mathrm{C}\right)\end{array}$ & References \\
\hline \multirow[t]{6}{*}{$\mathrm{Cd}(\mathrm{II})$} & Chitosan/clay beads & 72.31 & 25 & Tirtom et al. (2012) \\
\hline & $\begin{array}{l}\text { Chitosan/cotton fibres (via Schiff base } \\
\text { bond) }\end{array}$ & 15.74 & 25 & Zhang et al. (2008) \\
\hline & Chitosan/glutaraldehyde & 32.9 & 25 & Vitali et al. (2008) \\
\hline & Chitosan/perlite & 178.6 & 25 & Shameem et al. (2006) \\
\hline & Chitosan/PVA & 142.9 & 50 & Kumar et al. (2009) \\
\hline & Chitosan/xanthate & 357.14 & RT & $\begin{array}{l}\text { Sankararamakrishnan } \\
\text { et al. (2007) }\end{array}$ \\
\hline $\mathrm{Co}(\mathrm{II})$ & Chitosan/clinoptilolite & 467.90 & 25 & Dinu and Dragan (2010) \\
\hline Cr(III) & Chitosan/Reactive Blue 2 & 11.2 & 25 & $\begin{array}{l}\text { Vasconcelos et al. } \\
\text { (2007) }\end{array}$ \\
\hline \multirow[t]{6}{*}{$\mathrm{Cr}(\mathrm{VI})$} & $\begin{array}{l}\text { Chitosan coated acid treated oil palm } \\
\text { shell charcoal (CCAB) }\end{array}$ & 60.25 & & $\begin{array}{l}\text { Nomanbhay and } \\
\text { Palanisamy (2005) }\end{array}$ \\
\hline & $\begin{array}{l}\text { Chitosan coated oil palm shell charcoal } \\
\text { (CCB) }\end{array}$ & 52.68 & & $\begin{array}{l}\text { Nomanbhay and } \\
\text { Palanisamy (2005) }\end{array}$ \\
\hline & Chitosan/ceramic alumina & 153.8 & 25 & Veera et al. (2003) \\
\hline & Magnetic chitosan & 69.40 & & Huang et al. (2009) \\
\hline & Chitosan/montmorillonite & 41.67 & 25 & Fan et al. (2006) \\
\hline & Chitosan/perlite & 153.8 & 25 & Shameem et al. 2003 \\
\hline \multirow[t]{4}{*}{$\mathrm{Cu}(\mathrm{II})$} & Chitosan/alginate & 67.66 & & $\begin{array}{l}\text { Wan Ngah and } \\
\text { Fatinathan (2008) }\end{array}$ \\
\hline & Chitosan/cellulose & 26.50 & 25 & Sun et al. (2009) \\
\hline & Chitosan/clinoptilolite & 574.49 & & Dragan et al. (2010) \\
\hline & Chitosan/clinoptilolite & 719.39 & 25 & Dinu and Dragan (2010) \\
\hline
\end{tabular}

The reported metal adsorption capacities of wheat-based materials could depend on the structure of wheat bran used in different studies, along with other parameters.

Chitin, chitosan and chitosan composites

Chitin is a naturally and abundant occurring mucopolysaccharide from exoskeletons of insects, crustaceans shells, fungi cellular walls, annelids and molluscs. It is the second most abundant polymerin nature after cellulose. Chitin contains 2 -acetamido-2-deoxy- $\beta$-D-glucose through a $\beta$ $(1 \rightarrow 4)$ linkage. Through deacetylation process of chitin, a type of natural poly(aminosaccharide) so-called chitosan is produced. The chitosan consists mainly of poly $(1 \rightarrow 4)-2$ amino-2-deoxy-D-glucose unit, and this derivative biopolymer has been known as a promising polymeric material of great scientific interest due to its special characteristics, for instance, hydrophilicity, biocompatibility, biodegradability, non-toxicity, good adsorption properties and wide range of applications. The chitosan has drawn particular attention for its feasible application in a variety of forms, from flake-types to gels, beads and fibres. Due to high content of amino and hydroxyl groups in chitosan, this by-product material has been found to be able on adsorbing several heavy metals, including copper, chromium, silver, platinum and lead physically or chemically. In fact, chitosan has binding capacities of more than $1 \mathrm{mmol} / \mathrm{g}$ for heavy metals which is far greater than that of activated carbon.

The extend of metal adsorption depends strongly on the chitosan source, deacetylation degree, nature of metal ion, variations in crystallinity, amino content and solution $\mathrm{pH}$. A great number of chitosan derivatives have been obtained by introducing selected functional groups into the polymeric matrix of chitosan in order to enhance its interaction with variety of metallic ions, thus increase the adsorption capacity and selectivity for metal ions in solution. The reported chitosan derivatives are those containing nitrogen, phosphorus and sulphur as heteroatoms, and other derivatives such as chitosan crown ethers and chitosan ethylenediaminetetraacetic acid (EDTA)/diethylenetriaminepentaacetic acid (DTPA) complexes. Apart from that, chitosan composites have also been extensively investigated for heavy metal removal. Various types of substance have been used to form composite with chitosan, including activated clay, bentonite, montmorillonite, polyurethane, poly vinyl alcohol, poly vinyl chloride, kaolinite, oil palm ash and perlite. Table 6 shows the heavy metal removal capacities through adsorption process using these modified chitosan materials. 


\section{Conclusions}

Removal of heavy metals from aqueous environment is indeed a challenging problem in the control of environmental pollution. A wide range of treatment technologies such as chemical precipitation, ion exchange, membrane filtration and adsorption can be employed to remove heavy metals, but these treatment methods still suffer from some inherent limitations. For instance, chemical precipitation, which has been traditionally and widely used to remove heavy metals from contaminated sources, is often associated with huge sludge production. Ion exchange process is generally applicable to treat or remove heavy metals at low concentration. As for membrane filtration, problems such as membrane fouling, high maintenance cost and low permeate flux are often unavoidable. Taking all these into considerations, the adsorption process thus appeared as one of the most promising methods. Various low-cost adsorbents have been investigated intensively in order to avoid the usage of costly activated carbon. It is evident that in most of the reported works, the study is still being centralized in the maximum adsorption capacities of the materials. While most of the low-cost adsorbents have shown its potential in heavy metal removal without any modifications, but it is interesting to note that their removal capabilities can generally be improved through certain chemical modifications. Also, more than one factors such as $\mathrm{pH}$, contact time, initial influent concentration, temperature, adsorbent and dosage can significantly affect the adsorption process.

\section{Future direction}

Several low-cost adsorbents can be seen as attractive alternatives for the removal of heavy metals based on their outstanding removal ability. However, in most of the cases, attention seems to be focused on the maximum adsorption capacity of the low-cost adsorbents and the model pollutants are mainly synthetic types. In order to fully utilize the application of these materials in wastewater treatment, their removal efficiency should be further tested in effluents from industries. Besides, the characterization of the adsorbents as well as the study of the sorption mechanism is equally important. More effort is required to provide insight into the direction of modelling, the effects of adsorbent recycling and regeneration and the recovery of heavy metals from wastewater. The possibility of immobilized these adsorbents can also be viewed as a feasible approach as suspended system requires a filtration step which is not suited for practical applications. If modification is needed, it is desirable to have a material with a wide range of metal affinities as this will be particularly useful for industrial effluents which carry more than one type of metals. Further research involving the combination of methodologies/system should also be encouraged as this would minimize or overcome the problem associated with a single treatment process.

Acknowledgments The financial support by the International Foundation for Science, Stockholm, Sweden, and the research facil ities by Universiti Tunku Abdul Rahman are acknowledged.

\section{References}

Abo El Enein SA, Eissa MA, Diafullah AA, Rizk MA, Mohamed FM (2009) Removal of some heavy metals ions from wastewater by copolymer of iron and aluminium impregnated with active silica derived from rice husk ash. J Hazard Mater 172:574 579

Abo Farha SA, Abdel Aal AY, Ashour IA, Garamon SE (2009) Removal of some heavy metal cations by synthetic resin purolite C100. J Hazard Mater 169:190 194

Afkhami A, Saber Tehrani M, Bagheri H (2010) Simultaneous removal of heavy metal ions in wastewater samples using nano alumina modified with 2,4 dinitrophenylhydrazine. J Haz ard Mater 181:836 844

Agency for Toxic Substances and Disease Registry (ATSDR) (2005) Toxicological profile for nickel. U.S. Department of Health and Human Services, Public Health Service, Atlanta, GA

Ajmal M, Rao RAK, Anwar S, Ahmad J, Ahmad R (2003) Adsorption studies on rice husk: removal and recovery of $\mathrm{Cd}(\mathrm{II})$ from wastewater. Bioresour Technol 86:147 149

Al Enezi G, Hamoda MF, Fawzi N (2004) Ion exchange extraction of heavy metals from wastewater sludges. J Environ Sci Health A Tox Hazard Subst Environ Eng 39(2):455 464

Banerjee SS, Jayaram RV, Joshi MV (2003) Removal of nickel and zinc(II) from wastewater using fly ash and impregnated fly ash. Sep Sci Technol 38:1015 1032

Banerjee SS, Joshi MV, Jayaram RV (2004) Removal of Cr(VI) and $\mathrm{Hg}$ (II) from aqueous solution using fly ash and impregnated fly ash. Sep Sci Technol 39:1611 1629

Bansal M, Garg U, Singh D, Garg VK (2009) Removal of Cr(VI) from aqueous solutions using pre consumer processing agricul tural waste: a case study of rice husk. J Hazard Mater $162: 312320$

Bayat B (2002a) Combined removal of zinc (II) and cadmium (II) from aqueous solutions by adsorption onto high calcium Turkish fly ash. Water Air Soil Pollut 136:6992

Bayat B (2002b) Comparative study of adsorption properties of Turkish fly ashes: I. The case of nickel(II), copper(II) and zinc(II). J Hazard Mater 95:251 273

Cetin C, Pehlivan E (2007) The use of fly ash as a low cost, environmentally friendly alternative to activated carbon for the removal of heavy metals from aqueous solutions. Colloids Surf A Physicochem Eng Asp 298:83 87

Chojnacka K (2006) Biosorption of Cr(III) ions by wheat straw and grass: a systematic characterization of new biosorbents. Pol J Environ Stud 15:845 852

Dang VBH, Doan HD, Dang Vu T, Lohi A (2009) Equilibrium and kinetics of biosorption of cadmium (II) and copper (II) ions by wheat straw. Bioresour Technol 100:211 219

Dhir B, Kumar R (2010) Adsorption of heavy metals by salvinia biomass and agricultural residues. Int J Environ Res 4:427 432

Diamadopoulos E, Loannidis S, Sakellaropoulos GP (1993) As(V) removal from aqueous solutions by fly ash. Water Res 27:1773 1777 
Dinu MV, Dragan ES (2010) Evaluation of $\mathrm{Cu}^{2+}, \mathrm{Co}^{2+}$, and $\mathrm{Ni}^{2+}$ ions removal from aqueous solution using a novel chitosan/ clinoptilolite composites: kinetics and isotherms. Chem Eng J 160:157 163

Djedidi Z, Bouda M, Souissi MA, Cheikh RB, Mercier G, Tyagi RD, Blais J (2009) Metals removal from soil, fly ash and sewage sludge leachates by precipitation and dewatering properties of the generated sludge. J Hazard Mater 172:1372 1382

Dragan ES, Dinu MV, Timpu D (2010) Preparation and character ization of novel composites based on chitosan and clinoptilolite with enhanced adsorption properties for $\mathrm{Cu}^{2+}$. Bioresour Tech nol 101:812 817

Dupont L, Guillon E (2003) Removal of hexavalent chromium with a lignocellulosic substrate extracted from wheat bran. Environ Sci Technol 37:4235 4241

Dupont L, Bouanda J, Dumonceau J, Aplincourt M (2005) Biosorp tion of $\mathrm{Cu}(\mathrm{II})$ and $\mathrm{Zn}(\mathrm{II})$ onto a lignocellulosic substrate extracted from wheat bran. Environ Chem Lett 2:165 168

Elouear Z, Bouzid Z, Boujelben J, Feki N, Jamoussi M, Montiel FA (2008) Heavy metal removal from aqueous solutions by activated phosphate rock. J Hazard Mater 156:412 420

Fan DH, Zhu XM, Xu MR, Yan JL (2006) Adsorption properties of chromium (VI) by chitosan coated montmorillonite. J Bio Sci 6:941 945

Farajzadeh MA, Monji AB (2004) Adsorption characteristics of wheat bran towards heavy metal cations. Sep Purif Technol 38:197 207

Farooq U, Khan MA, Atharc M, Kozinskia JA (2011) Effect of modification of environmentally friendly biosorbent wheat (Triticum aestivum) on the biosorptive removal of cadmium(II) ions from aqueous solution. Chem Eng J 171:400 410

Feng Q, Lin Q, Gong F, Sugita S, Shoya M (2004) Adsorption of lead and mercury by rice husk ash. J Colloid Interface Sci 278:1 8

Feroze N, Ramzan N, Khan A, Cheema II (2011) Kinetic and equilibrium studies for $\mathrm{Zn}$ (II) and $\mathrm{Cu}$ (II) metal ions removal using biomass (rice husk) Ash. J Chem Soc Pak 33:139 146

Fu F, Wang Q (2011) Removal of heavy metal ions from wastewaters: a review. J Environ Manage 92:407 418

Gan Q (2000) A case study of microwave processing of metal hydroxide sediment sludge from printed circuit board manufac turing wash water. Waste Manage 20:695 701

Ghorbani M, Lashkenari MS, Eisazadeh H (2011) Application of polyaniline nanocomposite coated on rice husk ash for removal of $\mathrm{Hg}$ (II) from aqueous media. Synth Met 161:1430 1433

Ghorbani M, Eisazadeh H, Ghoreyshi AA (2012) Removal of zinc ions from aqueous solution using polyaniline nanocomposite coated on rice husk. Iran J Energ Environ 3(1):66 71

Gong R, Guan R, Zhao J, Liu X, Ni S (2008) Citric acid functionalizing wheat straw as sorbent for copper removal from aqueous solution. J Health Sci 54:174 178

Goswami D, Das AK (2000) Removal of arsenic from drinking water using modified fly ash bed. Int J Water 1:61 70

Gupta VK, Ali I (2000) Utilisation of bagasse fly ash (a sugar industry waste) for the removal of copper and zinc from wastewater. Sep Purif Technol 18:131 140

Gupta VK, Ali I, Jain CK, Sharma M, Saini VK (2003) Removal of cadmium and nickel from wastewater using bagasse fly ash a sugar industry waste. Water Res 37:4038 4044

Hindmarsh JT, McCurdy RF (1986) Clinical and environmental aspects of arsenic toxicity. Crit Rev Clin Lab Sci 23:315 347

Hsu TC, Yu CC, Yeh CM (2008) Adsorption of $\mathrm{Cu}^{2+}$ from water using raw and modified coal fly ashes. Fuel 87:1355 1359

Huang GL, Zhang HY, Jeffrey XS, Tim AGL (2009) Adsorption of chromium(VI) from aqueous solutions using cross linked mag netic chitosan beads. Ind Eng Chem Res 48:2646 2651
Iyer RS, Scott JA (2001) Power station fly ash a review of value added utilization outside of the construction industry. Resour Conserv Recycl 31:217 228

Johan NA, Kutty SRM, Isa MH, Muhamad NS, Hashim H (2011) Adsorption of copper by using microwave incinerated rice husk ash (MIRHA). Int J Civil Environ Eng 3:211 215

Karthikeyan KG, Elliott HA, Cannon FS (1996) Enhanced metal removal from wastewater by coagulant addition. Proc 50th Purdue Industrial Waste Conf 50: 259267

Keng PS, Lee SL, Ha ST, Hung YT, Ong ST (2013) Cheap materials to clean heavy metal polluted waters. In: Lichtfouse E et al. (eds) Green Materials for Energy, Products and Depollution. Envi ronmental Chemistry for a Sustainable World, vol 3

Krishnani KK, Meng X, Christodoulatos C, Boddu VM (2008) Biosorption mechanism of nine different heavy metals onto biomatrix from rice husk. J Hazard Mater 153:1222 1234

Kumar M, Bijay PT, Vinod KS (2009) Crosslinked chitosan/polyvinyl alcohol blend beads for removal and recovery of $\mathrm{Cd}(\mathrm{II})$ from wastewater. J Hazard Mater 172:1041 1048

Kung Y, Jung IL (2001) Photocatalytic reduction of $\mathrm{Cr}(\mathrm{VI})$ in aqueous solutions by UV irradiation with the presence of titanium dioxide. Water Res 35:135 142

Kurniawan TA, Chan YSG, Lo W, Babel S (2006) Physico chemical treatment techniques for wastewater laden with heavy metals. Chem Eng J 118:83 98

Lacour S, Bollinger J, Serpaud B, Chantron P, Arcos R (2001) Removal of heavy metals in industrial wastewaters by ion exchanger grafted textiles. Anal Chim Acta 428:121 132

Lee IH, Kuan Y, Chern J (2006a) Factorial experimental design for recovering heavy metals from sludge with ion exchange resin. J Hazard Mater B138:549 559

Lee J, Kwon T, Moon I (2006b) Performance of polyamide reverse osmosis membranes for steel wastewater reuse. Desalination 189:309 322

Lee CK, Low KS, Liew SC, Choo CS (1999) Removal of arsenic $(V)$ from aqueous solution by quaternized rice husk. Environ Technol 20:971 978

Lewis A, Van Hille R (2006) An exploration into the sulphide precipitation method and its effect on metal sulphide removal. Hydrometallurgy 81:197 204

Lin CJ, Chang JE (2001) Effect of fly ash characteristics on the removal of $\mathrm{Cu}(\mathrm{II})$ from aqueous solution. Chemosphere 44:1185 1192

Lu Z, Maroto Valer MM, Schobert HH (2008) Role of active sites in the steam activation of high unburned carbon fly ashes. Fuel 87:2598 2605

Luo X, Deng Z, Lin X, Zhang C (2011) Fixed bed column study for $\mathrm{Cu}^{2+}$ removal from solution using expanding rice husk. J Hazard Mater 187:182 189

Marshall WE, Champagne ET, Evans WJ (1993) Use of rice milling byproducts (hulls and bran) to remove metal ions from aqueous solution. J Environ Sci Health A28:1977 1992

Matlock MM, Howerton BS, Atwood DA (2002) Chemical precip itation of heavy metals from acid mine drainage. Water Res 36:4757 4764

Meunier N, Drogui P, Montané C, Hausler R, Mercier G, Blais J (2006) Comparison between electrocoagulation and chemical precipitation for metals removal from acidic soil leachate. J Hazard Mater B137:581 590

Mimura H, Yokota K, Akiba K, Onodera Y (2001) Alkali hydro thermal synthesis of zeolites from coal fly ash and their uptake properties of cesium ion. J Nucl Sci Technol 38:766 772

Mirbagheri SA, Hosseini SN (2005) Pilot plant investigation on petrochemical wastewater treatment for the removal of copper and chromium with the objective of reuse. Desalination 171:8593 
Nadzi BS, Nyahumwa C, Tesha J (2007) Chemical and thermal stability of rice husks against alkali treatment. BioResources 3(4):1267 1277

Nakbanpote W, Thiravavetyan P, Kalambaheti C (2002) Comparison of gold adsorption by Chlorella vulgaris, rice husk and activated carbon. Miner Eng 15:549 552

Nakbanpote W, Goodman BA, Thiravetyan P (2007) Copper adsorp tion on rice husk derived materials studied by EPR and FTIR. Colloids Surf A Physicochem Eng Asp 304:7 13

Nomanbhay SM, Palanisamy K (2005) Removal of heavy metal from industrial wastewater using chitosan coated oil palm shell charcoal. Electron J Biotechnol 8:43 53

Özer A, Pirincci HB (2006) The adsorption of Cd(II) ions on sulfuric acid treated wheat bran. J Hazard Mater B 137:849 855

Papandreou A, Stournaras CJ, Panias D (2007) Copper and cadmium adsorption on pellets made from fired coal fly ash. J Hazard Mater 148:538 547

Papandreou A, Stournaras CJ, Panias D, Paspaliaris I (2011) Adsorption of $\mathrm{Pb}(\mathrm{II}), \mathrm{Zn}(\mathrm{II})$ and $\mathrm{Cr}(\mathrm{III})$ on coal fly ash porous pellets. Miner Eng 24:1495 1501

Pattanayak J, Mondal K, Mathew S, Lalvani SB (2000) A parametric evaluation of the removal of $\mathrm{As}(\mathrm{V})$ and $\mathrm{As}(\mathrm{III})$ by carbon based adsorbents. Carbon 38:589 596

Pengthamkeerati P, Satapanajaru T, Singchan O (2008) Sorption of reactive dye from aqueous solution on biomass fly ash. J Hazard Mater 153:1149 1156

Pillai MG, Regupathi I, Kalavathy MH, Murugesan T, RoseMiranda L (2009) Optimization and analysis of nickel adsorption on microwave irradiated rice husk using response surface method ology (RSM). J Chem Technol Biotechnol 84:291 301

Polowczyk I, Bastrzyk A, Sawinski W, Kozlecki T, Rudnicki P, Sadowski Z (2011) Sorption properties of fly ash from brown coal burning towards arsenic removal. Techn Trans Chem 8:135 142

Rao M, Parwate AV, Bhole AG, Kadu PA (2003) Performance of low cost adsorbents for the removal of copper and lead. J Water Suppl Res Technol AQUA 52:49 58

Roy D, Greenlaw PN, Shane BS (1993) Adsorption of heavy metals by green algae and ground rice hulls. J Environ Sci Health A28:37 50

Salehi E, Madaeni SS, Heidary F (2012) Dynamic adsorption of Ni(II) and $\mathrm{Cd}(\mathrm{II})$ ions from water using 8 hydroxyquinoline ligand immobilized PVDF membrane: isotherms, thermodynamics and kinetics. Sep Purif Technol 94:1 8

Sankararamakrishnan N, Sharma AK, Sanghi R (2007) Novel chitosan derivative for the removal of cadmium in the presence of cyanide from electroplating wastewater. J Hazard Mater 148:353 359

Shameem H, Abburi K, Tushar KG, Dabir SV, Veera MB, Edgar DS (2003) Adsorption of chromium(VI) on chitosan coated perlite. Sep Sci Technol 38:3775 3793

Shameem H, Abburi K, Tushar KG, Dabir SV, Veera MB, Edgar DS (2006) Adsorption of divalent cadmium (Cd(II)) from aqueous solutions onto chitosan coated perlite beads. Ind Eng Chem Res 45:5066 5077

Sharma N, Kaur K, Kaur S (2009) Kinetic and equilibrium studies on the removal of $\mathrm{Cd}^{2+}$ ions from water using polyacrylamide grafted rice (Oryza sativa) husk and (Tectona grandis) saw dust. J Hazard Mater 163:1338 1344

Singh KK, Hasan HS, Talat M, Singh VK, Gangwar SK (2009) Removal of $\mathrm{Cr}(\mathrm{VI})$ from aqueous solutions using wheat bran. Chem Eng J 151:113 121
Srivastava NK, Majumder CB (2008) Novel biofiltration methods for the treatment of heavy metals from industrial wastewater. J Hazard Mater 151:1 8

Srivastava VC, Mall ID, Mishra IM (2008) Removal of cadmium(II) and zinc(II) metal ions from binary aqueous solution by rice husk ash. Colloids Surf A Physicochem Eng Aspects 312:172 184

Sun XQ, Peng B, Jing Y, Chen J, Li DQ (2009) Chitosan(chitin)/ cellulose composite biosorbents prepared using ionic liquid for heavy metal ions adsorption. Separations 55:2062 2069

Tarley CRT, Ferreira SLC, Arruda MAZ (2004) Use of modified rice husks as a natural solid adsorbent of trace metals: characterisa tion and development of an online preconcentration system for cadmium and lead determination by FAAS. Microchem $\mathrm{J}$ 77:163 175

Tirtom VN, Dincer A, Becerik S, Aydemir T, Celik A (2012) Comparative adsorption of $\mathrm{Ni}(\mathrm{II})$ and $\mathrm{Cd}(\mathrm{II})$ ions on epichloro hydrin crosslinked chitosan clay composite beads in aqueous solution. Chem Eng J 197:379 386

Vasconcelos HL, Fávere VT, Goncalves NS, Laranjeira MCM (2007) Chitosan modified with reactive blue 2 dye on adsorption equilibrium of $\mathrm{Cu}(\mathrm{II})$ and $\mathrm{Ni}(\mathrm{II})$ ions. React Funct Polym 67:1052 1106

Veeken AHM, Akoyo L, Hulshoff Pol LW, Weijma J (2003) Control of the sulfide $\left(\mathrm{S}^{2-}\right)$ concentration for optimal zinc removal by sulfide precipitation in a continuously stirred tank reactor. Water Res 37:3709 3717

Veera MB, Krishnaiah A, Jonathan LT, Edgar DS (2003) Removal of hexavalent chromium from wastewater using a new composite chitosan biosorbent. Environ Sci Technol 37:4449 4456

Visa M, Isac L, Duta A (2012) Fly ash adsorbents for multi cation wastewater treatment. Appl Surf Sci 258:6345 6352

Vitali L, Laranjeira MCM, Goncalves NS, Fávere VT (2008) Spray dried chitosan microspheres containing 8 hydroxyquinoline 5 sulphonic acid as a new adsorbent for $\mathrm{Cd}(\mathrm{II})$ and $\mathrm{Zn}$ (II) ions. Int J Biol Macromol 42:152 157

Wan Ngah WS, Fatinathan S (2008) Adsorption of $\mathrm{Cu}(\mathrm{II})$ ions in aqueous solution using chitosan beads, chitosan GLA beads and chitosan alginate beads. Chem Eng J 143:62 72

Wang S, Li H (2007) Kinetic modelling and mechanism of dye adsorption on unburned carbon. Dye Pigments 72:308 314

Wang XS, Li ZZ, Sun C (2009) A comparative study of removal of $\mathrm{Cu}$ (II) from aqueous solutions by locally low cost materials: marine macroalgae and agricultural by products. Desalination 235:146 159

Wang X, Xia L, Tan K, Zheng W (2011) Studies on adsorption of uranium(VI) from aqueous solution by wheat straw. Environ Prog Sustain Energy 31:566 576

Wen Y, Tang Z, Chen Y, Gu Y (2011) Adsorption of Cr(VI) from aqueous solutions using chitosan coated fly ash composite as biosorbent. Chem Eng J 175:110 116

Weng CH, Huang CP (2004) Adsorption characteristics of Zn(II) from dilute aqueous solution by fly ash. Colloids Surf A Physicochem Eng Asp 247:137 143

Ye H, Zhu Q, Du D (2010) Adsorptive removal of Cd(II) from aqueous solution using natural and modified rice husk. Bioresour Technol 101:5175 5179

Ye H, Zhang L, Zhang B, Wu G, Du D (2012) Adsorptive removal of $\mathrm{Cu}$ (II) from aqueous solution using modified rice husk. Int J Eng Res Appl 2(2):855 863

Zhang GY, Qu RJ, Sun CM, Ji CN, Chen H, Wang CH (2008) Adsorption for metal ions of chitosan coated cotton fiber. J Appl Polym Sci 110:2321 2327 